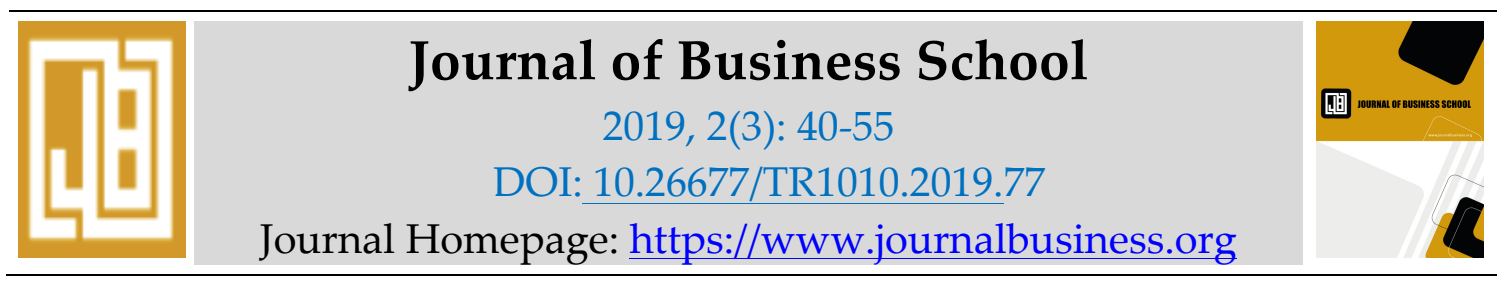

\title{
Women's Voice in Business Policy Shaping Spaces in Bangladesh
}

\author{
S. M. Khaled Hossain \\ Lecturer, Army Institute of Business Administration (AIBA), Dhaka, Bangladesh. \\ smkhossain19@gmail.com
}

\section{Md. Rahat Khan}

Assistant Professor, Department of Business Administration, City University, Dhaka, Bangladesh.rahatkhan.mrk14@gmail.com

\begin{abstract}
The current research emphasizes on development of women entrepreneurs in suburban areas of Bangladesh and their scope in participation in policy formulation to achieve economic independence and empowerment. Women entrepreneurship has been playing a pivotal role in terms of economic growth employment generation and industrialization. In urban area nearly $15.4 \%$ of the $36.7 \%$ self-employed people are women. In rural area, it is only $7.4 \%$ (Statistical Pocketbook, Bangladesh '99). A general observation says that the participation women in business entrepreneurship have developed over last decade. This report is an endeavor to find out major challenges that obstruct smooth development of women entrepreneurs and sociodemographic profile of women entrepreneurs. Mostly primary data has been used to find out the major objective. Literature has been reviewed from different perceptions. The research specially focused to the extent of the participation of women entrepreneurs in policy formulation. The study was done on the districts as well-known as greater Mymensingh. Overall perception of women entrepreneurs about existing business environment were also tried to discover through this study. The study concludes with the massage that still in present age women, although doing businesses, are getting little chance to contribute in policy formulation regarding their business which are still done through male dominated bodies like chambers of commerce, other formal and informal associations etc. The research feels necessity to have further study to make the way out and suggest the nation the better solutions in this regard.
\end{abstract}

Keywords: Empowerment, Participation, Sustainable, Arena, Sensitivity.

\section{Introduction}

Women are an effective monetary force. For a nation's development, they make essential commitments as entrepreneurs and employees. The advancement of ladies in associations, Decision making, Political investment and sex mainstreaming is presently seen as the overwhelming theoretical model for advancing social equity and ladies correspondence. Women's economic empowerment is an inevitable part of development discourse. Without women from the conventional development program, institutionalization of a sustainable 
development process is just ridiculous. People's long lasting thrust for a participatory democracy in Bangladesh also requires a sustainable economic growth. Until now, this growth would always be untouchable without active and meaningful contribution of the country's women folks. They give a key chance to monetary and social improvement and advance.Existing sex proportion in demographic structure of Bangladesh shows that ladies include right around half of the aggregate populace. They are vital piece of country's HR. Because of this demographic structure, the issue of the interest of ladies in the standard economy is basic. Without a meaningful and active participation of women, half of the total population, in regular economic activities, a dynamic and sustainable economy is impossible. A feasible economy is a prerequisite for national growth and prosperity including institutionalization of a democratic system. It is not possible to achieve the target of a povertyfree society without incorporation of women in the mainstream economy. However, Women's role in decision-making is one of the most significant questions for contemplation in the movement for their empowerment. Women's contribution in the workplace, leadership role in the political and social arenas and access to credit may be viewed as empowerment of women. It is a process that allows women to gain access to and control over the physical resources as well as in the power structure. It is an instrument of awareness and capacity building leading to greater participation in the decision making process.But the process of women's empowerment is hindered by various difficulties. Mainly Most of the society of our country is male commanding society as a result women are in helpless situation. Each stride towards ladies uniformity is a battle against of social standards. It is a traditional belief that generally males make all major decisions and at the same time they contribute to business arenas more than females, and thus, our society is highly male dominated, which is popularly known as gender bias against female. However the present study is conducted to examine how the gender sensitivity of policy processes in the national economy can be enhanced in greater Mymensingh (especially in business and trade spheres) in order to improve the benefits of policy formulation for women. The study is also designed to portrait real scenery of women entrepreneurs' participation in decision making and policy formulation in various business spheres. 230 respondents from six district of greater Mymensingh i.e., Mymensingh, Jamalpur, Sherpur, Netrokona, Tangail and Kishoregonj are taken as sample for conducting this research study. It has been found that women are in susceptible situation in case of policy formulation and decision making in business arenas. The study also attempts to give some suggestion to improve this condition. The government as well as all the concerned authority should come forward with considerable efforts to ensure proper participation of women entrepreneurs' in decision making and policy formulation for smooth running and sustainable development in this sector which will result in overall economic development of Bangladesh.

\section{Objectives of the Study}

The study is focused:

1. to examine how the gender sensitivity of policy processes in the national economy can be enhanced in greater Mymensingh (especially in business and trade spheres) in order to improve the benefits of policy formulation for women;

2. to conceptualize the positives and negatives of national economic processes for women;

3. to examine how awareness can be raised amongst key policy actors of implications of their interventions for women;

4. to explore how women's voice and perspectives of greater Mymensingh area can be better articulated in national economic policy spaces by policy and civil society actors able to influence the process; and 
5. to support conceptualization of the existing and potential trade and policy leader of the geographical area with a final expectation of enhancement of the beneficial impacts and reduction of the negative impacts of interventions by national trade and policy actors on women.

\section{Methodology of the Study}

The subject matters related to methodological aspects of this report are the following:

\subsection{Sources of data:}

\begin{tabular}{|c|c|}
\hline Primary sources & Secondary sources \\
\hline $\begin{array}{l}\text { Direct interview by using structured } \\
\text { questionnaire }\end{array}$ & $\begin{array}{l}\text { Different books, publications and } \\
\text { journals }\end{array}$ \\
\hline Field survey & Different magazines and newspapers \\
\hline Business academics opinion & Internet and websites \\
\hline
\end{tabular}

\subsection{Data collection:}

Primary data is collected from different district areas under greater Mymensingh specifically Mymensingh, Jamalpur, Sherpur, Netrokona, Tangail and Kishoregonj on the current involvements of women in business and trade policy with a standard questionnaire survey. Secondary data is collected through analytical works based on a review of the literature. Critical analytical approaches will provide a base to advance conceptual thinking on women's engagement with global economic policy processes of national and greater Mymensingh area.

\subsection{Sample selection technique:}

For our research purpose sample is selected randomly. Our targeted sample was 360 (for Women Entrepreneurs 120, Representatives of Chamber of Commerce and Industry/ Association 120 and Business Students and Academics 120). Actual response obtained from targeted sample was 230 (from Women Entrepreneurs 67, Representatives of Chamber of Commerce and Industry/ Association 43 and Business Students and Academics 120).

\subsection{Sample size:}

The total sample size for this research is 230. The targeted respondents are categorized into three categories that are Women Entrepreneurs, representatives of Chamber of Commerce and Industry/ Association and Business Students and Academics. Data from 67 Women Entrepreneurs, 43 members of Chamber of Commerce and Industry/ Association and 120 Business Academics are collected through a structured questionnaire for the research purpose.

\subsection{Types of information:}

A structured questionnaire has been served as a data collecting instrument. The questionnaire contains 17 specific questions. In order to take answer of the questions from the respondents there is used a 05 point Likert scale ranging from 01 to 05 . In which 05 indicates "strongly agree", 04 indicates "agree", 03 indicates "Neutral", 02 indicates "disagree", 01 indicates "strongly disagree".

\subsection{Scope of the Study:}

The study was conducted in different district areas under greater Mymensingh specifically Mymensingh, Jamalpur, Sherpur, Netrokona, Tangail and Kishoregonj. A short summary of selected areas are portrayed below: 


\begin{tabular}{|c|c|c|c|c|c|c|}
\hline District Name & $\begin{array}{c}\text { Area } \\
\text { (Sq. } \\
\text { Killo) }\end{array}$ & $\begin{array}{c}\text { Establishing } \\
\text { Year }\end{array}$ & $\begin{array}{c}\text { Number } \\
\text { of } \\
\text { Upazilla }\end{array}$ & $\begin{array}{c}\text { Population } \\
\text { (Census } \\
\text { 2011) }\end{array}$ & $\begin{array}{c}\text { Education } \\
\text { rate }\end{array}$ & $\begin{array}{c}\text { Presence of } \\
\text { Industry }\end{array}$ \\
\hline Mymensingh & 4363.48 & 1787 & 13 & 5313163 & $30.10 \%$ & Present \\
\hline Jamalpur & 2031.98 & 1978 & 07 & 2382810 & $38.50 \%$ & Present \\
\hline Sherpur & 1363.76 & 1984 & 05 & 1407468 & $38.04 \%$ & Present \\
\hline Netrokona & 2810.40 & 1882 & 10 & 2229464 & $42.55 \%$ & Present \\
\hline Tangail & 3424.39 & 1969 & 11 & 3605083 & $46.80 \%$ & Present \\
\hline Kishoregonj & 2688.62 & 1984 & 13 & 3028706 & $40.30 \%$ & Present \\
\hline
\end{tabular}

Source: Field Survey, 2018

\subsection{Data analyzing process:}

Collected information is processed by the use of computer system. Various statistical tools such as $\mathrm{Z}$ test, weighted average, standard deviation, arithmetic means, percentage etc. are used for processing the data.

For $\mathrm{Z}$ test the following formula is used:

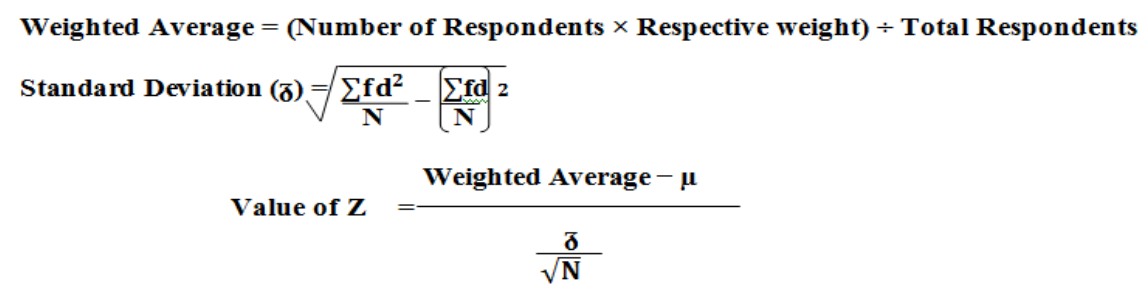

\section{Literature Review}

Khan (2006) and Mason and Smith(2003) definesempowerment as a process which enables women to meet both their practical and strategic needs and increases women's political power, consciousness about them and strengthens women's self-confidence.

Hossain and Jaim(2011) said in another study,women empowerment means the participation of women in household decision making process and contribution to the family income

Women empowerment consists of greater access to knowledge and resources, greater autonomy in decision making to enable them to have greater ability to plan their lives, or to have greater control over the circumstances that influence their lives and free from shocks imposed on them by custom, belief and practice (GU, 2005).

Lovely Parvin, JiaJinrong and M. WakilurRahman (2012) has conducted a study on women's participation in business and they argued in their study that, women have poor command over economic resources and policy space in comparison to men. The fact restricts the women especially in developing country like ours to have the intellectual inputs, employment of women labor. In many cases the employment area and career development are dominated by men. This hinders women's potentials to contribute in economic developments. According to World Bank in no developing country women enjoy equal economic, social, or legal rights compared to those of men. Nearly half of the population is women (sex ratio 10:6). The enormous potentiality of the population has been unutilized as few women participate in the mainstream of economic activities. For instance, only 16\% of women are self-employed out of $66 \%$ self-employed citizen (based on entrepreneurship status).

In another study, Rozana Majumdar (2012) find out that, in a country like Bangladesh, with a patriarchal social structure reinforced by religious, economic and political norms, it is 
challenging to advance the cause of women. The primary role of women is associated with the family - as biological reproducers and nurturers. In addition, women are responsible for all the domestic household work but lack decision-making power within the household. Because of the strong patriarchal structure, political positions for women are a privilege rather than a right. In order for women to mobilize and empower women, according to Srilatha Batliwala, they need to go through a "the process of challenging existing power relations, and of gaining greater control over the sources of power."

Parveen and Leonhäuser (2005) have said that education, skill acquisition training and exposure to information media help women to be empowered. The women who are engaged in any selfearning activities are more empowered because they have a great role in decision making, access to assets and their control over the self-earnings in Bangladesh.

Laizu et al., (2010) has conducted a research study on women's empowerment and suggests that, women have full and equalaccess to ICT based economic and educational activities supports their contribution in businessand home-based activities and helps them become more empowered.

Nawaz (2009) analyzes a variety of critical factors of women entrepreneurship development in rural Bangladesh. She depicts an analytical framework based on institutional theory, which focuses on three kinds of factors: regulative, normative, and cognitive. Regulative factors refer to different rules and regulations of the Government that facilitate women entrepreneurship development in rural Bangladesh. Normative and cognitive factors include norms, rules, regulation, and values of society. Based on the analysis of these factors, Nawaz provides various policy implications on how to improve women entrepreneurship development in rural Bangladesh.

ILO Area Office, (2009) said that, women are under-represented in executive bodies. This is evident not only by the number of women members and its attendant percentage of total executive body embers, but also in comparison with the percentage of women members in the respective trade union federations.

The Beijing Platform for Action considered the inequality between men and women in the sharing of power and decision- making at all levels as one of the critical areas of concern for the empowerment of women. It stated "Women's equal participation in decision- making is not only a demand for simple justice or democracy but can also be seen as a necessary condition for women's interests to be taken into account. Without the active participation of women and the incorporation of women's perspective at all levels of decision- making, the goals of equality, development and peace cannot be achieved".

Rahman, Mostafizur \& Fardausara (2006) in another study pointed out that, women's role in decision-making is one of the most important questions for consideration in the movement for their empowerment. Keeping in mind, the importance of women's participation in decisionmaking, like the other government in the world, the government of Bangladesh has initiated efforts to widen the scope of women for participation in the development process. The Local Government (Union Parishad) Second Amendment Act 1997 of Bangladesh is a mile stone towards ensuring women's equal access and increased participation in political power structures. This amendment provided for direct elections to reserved seats for women in local level elections. As a strategy of affirmative action for providing the structural framework for women's participation in political decision-making and provided an opportunity to bring women to the center of local development and develop new grass-roots level leadership. 
Journal of Business School, vol.2, issue.3, pp.40-55

\section{Data analysis and Findings}

Factor \#01: Female entrepreneurs' involvement in their business operation is satisfactory.

Table: 01

\begin{tabular}{|c|c|c|c|c|c|c|c|c|c|c|}
\hline & \multicolumn{6}{|c|}{ Description of Respondents } & \multirow[t]{2}{*}{ WA } & \multirow[t]{2}{*}{ SD } & \multirow{2}{*}{$\begin{array}{c}\text { Z-test } \\
\text { Cal. } \\
\text { Value }\end{array}$} & \multirow{2}{*}{$\begin{array}{c}\text { Z-test } \\
\text { Cri. } \\
\text { Value }\end{array}$} \\
\hline & SD & $\mathrm{D}$ & $\mathrm{N}$ & A & SA & Total & & & & \\
\hline Number & 47 & 92 & 18 & 68 & 05 & 230 & 2.53 & 1.17 & -6.03 & 1.96 \\
\hline Percentage & 20.43 & 40.00 & 7.83 & 29.56 & 2.18 & 100 & - & - & - & - \\
\hline
\end{tabular}

Source: Field Survey, 2018

$H_{0}=$ Female entrepreneurs' involvement in their business operation is not satisfactory.

$\mathrm{H}_{1}=$ Female entrepreneurs' involvement in their business operation is satisfactory.

From the total of our respondents it is found that, $20.43 \%$ respondents strongly disagreed, $40.00 \%$ respondents disagreed, $07.83 \%$ respondents are neutral, $29.56 \%$ respondents agreed and $02.18 \%$ respondents strongly agreed that female entrepreneurs' involvement in their business operation is satisfactory. Here, the calculated value of $Z$ is -6.03 and the critical value of $Z$ is 1.96. As the critical value of $Z$ is greater than the calculated value of $Z$ so the null hypothesis $\left(\mathrm{H}_{0}\right)$ is accepted and alternative hypothesis $\left(\mathrm{H}_{1}\right)$ is rejected.

Comment: Female entrepreneurs' involvement in their business operation is not satisfactory. It is not a positive sign for women development in Bangladesh. Without the effective participation of women in business arena women's empowerment can't be imagined which the perquisite of socio economic development of Bangladesh is. So, concerned authority should come forward to increase women's involvement in their business.

Factor\#02: Female entrepreneurs have opportunity to express their views about important matters.

Table: 02

\begin{tabular}{|c|c|c|c|c|c|c|c|c|c|c|}
\hline & \multicolumn{6}{|c|}{ Description of Respondents } & \multirow[t]{2}{*}{ WA } & \multirow[t]{2}{*}{ SD } & \multirow{2}{*}{$\begin{array}{c}\text { Z-test } \\
\text { Cal. } \\
\text { Value }\end{array}$} & \multirow{2}{*}{$\begin{array}{c}\text { Z-test } \\
\text { Cri. } \\
\text { Value } \\
\end{array}$} \\
\hline & SD & $\mathrm{D}$ & $\mathrm{N}$ & A & SA & Total & & & & \\
\hline Number & 37 & 102 & 26 & 62 & 03 & 230 & 2.53 & 1.09 & -6.53 & 1.96 \\
\hline Percentage & 16.09 & 44.35 & 11.30 & 26.96 & 1.30 & 100 & - & - & - & - \\
\hline
\end{tabular}

Source: Field Survey, 2018

$H_{0}=$ Female entrepreneurs have no opportunity to express their views about important matters. $\mathrm{H}_{1}=$ Female entrepreneurs have opportunity to express their views about important matters.

From the above table it has been seen that, $16.09 \%$ respondents strongly disagreed, $44.35 \%$ respondents disagreed, $11.30 \%$ respondents are neutral, $26.96 \%$ respondents agreed and $01.30 \%$ respondents strongly agreed that female entrepreneurs have opportunity to express their views about important matters. Here, the calculated value of $Z$ is -6.53 and the critical value of $Z$ is 1.96. Since, the critical value of $Z$ is higher than the calculated value of $Z$ so the null hypothesis $\left(\mathrm{H}_{0}\right)$ is accepted and alternative hypothesis $\left(\mathrm{H}_{1}\right)$ is rejected.

Comment: Mathematical analysis reveals that, female entrepreneurs' opportunity to express their views about important matters is very poor. They can't express their views freely. As a result they are deprived of expressing their views about any important topic. Such type of neglect acts as obstacles for women's empowerment. So opportunity should be created to enhance expressing power of women about important matters. 
Factor $\#$ 03: Female entrepreneurs can get enough opportunity in case of policy formulation and decision making.

Table: 03

\begin{tabular}{|c|c|c|c|c|c|c|c|c|c|c|}
\hline & \multicolumn{6}{|c|}{ Description of Respondents } & \multirow[t]{2}{*}{ WA } & \multirow[t]{2}{*}{ SD } & \multirow{2}{*}{$\begin{array}{c}\text { Z-test } \\
\text { Cal. } \\
\text { Value }\end{array}$} & \multirow{2}{*}{$\begin{array}{c}\text { Z-test } \\
\text { Cri. } \\
\text { Value }\end{array}$} \\
\hline & SD & $\mathrm{D}$ & $\mathrm{N}$ & A & SA & Total & & & & \\
\hline Number & 61 & 116 & 20 & 27 & 06 & 230 & 2.13 & 1.02 & -12.99 & 1.96 \\
\hline Percentage & 26.52 & 50.43 & 8.70 & 11.74 & 2.61 & 100 & - & - & - & - \\
\hline
\end{tabular}

Source: Field Survey, 2018

$H_{0}=$ Female entrepreneurs can't get enough opportunity in case of policy formulation and decision making.

$\mathrm{H}_{1}=$ Female entrepreneurs can get enough opportunity in case of policy formulation and decision making.

Field survey portraits that, from the total of our respondents $26.52 \%$ respondents strongly disagreed, $50.43 \%$ respondents disagreed, $08.70 \%$ respondents are neutral, $11.74 \%$ respondents agreed and $02.61 \%$ respondents strongly agreed that female entrepreneurs have enough opportunity in case of policy formulation and decision making. Here, the calculated value of $Z$ is -12.99 and the critical value of $Z$ is 1.96 . As the critical value of $Z$ is greater than the calculated value of $Z$ so the null hypothesis $\left(\mathrm{H}_{0}\right)$ is accepted and alternative hypothesis $\left(\mathrm{H}_{1}\right)$ is rejected.

Comment: Opportunity of policy formulation and decision making is a great indicator of women's empowerment. The present study highlights that woman entrepreneurs are also deprived of this opportunity. In case of policy formulation and decision making process women entrepreneurs are neglected. But efficient policy formulation and wise decision making is possible by women entrepreneurs. So, concerned authority should initiate proper steps to ensure women's active participation in policy formulation and decision making process.

Factor\#04: Female entrepreneurs get equal opportunity as like as male entrepreneurs in case of policy formulation and decision making.

Table: 04

\begin{tabular}{|c|c|c|c|c|c|c|c|c|c|c|}
\hline & \multicolumn{6}{|c|}{ Description of Respondents } & \multirow[t]{2}{*}{ WA } & \multirow[t]{2}{*}{ SD } & \multirow{2}{*}{$\begin{array}{c}\text { Z-test } \\
\text { Cal. } \\
\text { Value }\end{array}$} & \multirow{2}{*}{$\begin{array}{c}\text { Z-test } \\
\text { Cri. } \\
\text { Value }\end{array}$} \\
\hline & SD & $\mathrm{D}$ & $\mathrm{N}$ & $\mathrm{A}$ & SA & Total & & & & \\
\hline Number & 86 & 95 & 22 & 19 & 08 & 230 & 1.99 & 1.00 & -15.30 & 1.96 \\
\hline Percentage & 37.39 & 41.30 & 9.57 & 8.26 & 3.48 & 100 & - & - & - & - \\
\hline
\end{tabular}

Source: Field Survey, 2018

$H_{0}=$ Female entrepreneurs can't get equal opportunity as like as male entrepreneurs in case of policy formulation and decision making.

$\mathrm{H}_{1}=$ Female entrepreneurs get equal opportunity as like as male entrepreneurs in case of policy formulation and decision making.

From the total of our respondents it has been found that, $37.39 \%$ respondents strongly disagreed, $41.30 \%$ respondents disagreed, $09.57 \%$ respondents are neutral, $08.26 \%$ respondents agreed and $03.48 \%$ respondents strongly agreed that female entrepreneurs get equal opportunity as like as male entrepreneurs in case of policy formulation and decision making. Here, the calculated value of $Z$ is -15.30 and the critical value of $Z$ is 1.96 . Since the critical value 
of $\mathrm{Z}$ is greater than the calculated value of $\mathrm{Z}$ so the null hypothesis $\left(\mathrm{H}_{0}\right)$ is accepted and alternative hypothesis $\left(\mathrm{H}_{1}\right)$ is rejected.

Comment: The mathematical analysis shows the result that, female entrepreneurs can't get equal opportunity as like as male entrepreneurs in case of policy formulation and decision making process. Naturally, male entrepreneurs get priority in case of policy formulation and decision making. Such type of discrimination hampers women's empowerment in case of business arena.

Factor\#05: Female entrepreneurs' decision is fully accepted by the top authority.

Table: 05

\begin{tabular}{|c|c|c|c|c|c|c|c|c|c|c|}
\hline & \multicolumn{6}{|c|}{ Description of Respondents } & \multirow[t]{2}{*}{ WA } & \multirow[t]{2}{*}{ SD } & \multirow{2}{*}{$\begin{array}{l}\text { Z-test } \\
\text { Cal. } \\
\text { Value }\end{array}$} & \multirow{2}{*}{$\begin{array}{c}\text { Z-test } \\
\text { Cri. } \\
\text { Value }\end{array}$} \\
\hline & SD & $\mathrm{D}$ & $\mathrm{N}$ & A & SA & Total & & & & \\
\hline Number & 35 & 73 & 46 & 70 & 06 & 230 & 2.73 & 1.12 & -3.64 & 1.96 \\
\hline Percentage & 15.22 & 31.74 & 20.00 & 30.43 & 2.61 & 100 & - & - & - & - \\
\hline
\end{tabular}

Source: Field Survey, 2018

$H_{0}=$ Female entrepreneurs' decision is not fully accepted by the top authority. $\mathrm{H}_{1}=$ Female entrepreneurs' decision is fully accepted by the top authority.

From $100 \%$ of our respondents about $15.22 \%$ respondents strongly disagreed, $31.74 \%$ respondents disagreed, $20.00 \%$ respondents are neutral, $30.43 \%$ respondents agreed and $02.61 \%$ respondents strongly agreed that female entrepreneurs' decision is fully accepted by the top authority. Here, the calculated value of $Z$ is -3.64 and the critical value of $Z$ is 1.96 . As the critical value of $Z$ is greater than the calculated value of $Z$ so the null hypothesis $\left(H_{0}\right)$ is accepted and alternative hypothesis $\left(\mathrm{H}_{1}\right)$ is rejected.

Comment: Mathematical analysis reveals that acceptance of female entrepreneurs' decision by top authority is very poor. As a result they become frustrated and are discouraged to formulate policy and take decision.

Factor\#06: Female entrepreneurs' decision is fully implemented and practiced by the top authority.

Table: 06

\begin{tabular}{|c|c|c|c|c|c|c|c|c|c|c|}
\hline & \multicolumn{6}{|c|}{ Description of Respondents } & \multirow[t]{2}{*}{ WA } & \multirow[t]{2}{*}{ SD } & \multirow{2}{*}{$\begin{array}{c}\text { Z-test } \\
\text { Cal. } \\
\text { Value }\end{array}$} & \multirow{2}{*}{$\begin{array}{c}\text { Z-test } \\
\text { Cri. } \\
\text { Value }\end{array}$} \\
\hline & SD & $\mathrm{D}$ & $\mathrm{N}$ & A & SA & Total & & & & \\
\hline Number & 37 & 73 & 75 & 40 & 05 & 230 & 2.58 & 1.02 & -6.27 & 1.96 \\
\hline Percentage & 16.09 & 31.74 & 32.61 & 17.39 & 2.17 & 100 & - & - & - & - \\
\hline
\end{tabular}

Source: Field Survey, 2018

$H_{0}=$ Female entrepreneurs' decision is not fully implemented and practiced by the top authority. $H_{1}=$ Female entrepreneurs' decision is fully implemented and practiced by the top authority.

From data analysis it has been found that, $16.09 \%$ respondents strongly disagreed, $31.74 \%$ respondents disagreed, $32.61 \%$ respondents are neutral, $17.39 \%$ respondents agreed and $02.17 \%$ respondents strongly agreed that women entrepreneurs' decision is fully implemented and practiced by the top authority. Here, the calculated value of $Z$ is -6.27 and the critical value of $\mathrm{Z}$ is 1.96 . So the null hypothesis $\left(\mathrm{H}_{0}\right)$ is accepted and alternative hypothesis $\left(\mathrm{H}_{1}\right)$ is rejected. 
Comment: As female entrepreneurs' decision is not fully accepted by the top authority so it is clear that their decisions are not properly implemented and practiced by the concerned authority. Mathematical analysis portraits that female entrepreneurs' decision is not fully implemented and practiced by the top authority. So, social acceptance of female entrepreneurs' is disrupted

Factor\#07: Female entrepreneurs can utilize their skills fully.

Table: 07

\begin{tabular}{|c|c|c|c|c|c|c|c|c|c|c|}
\hline & \multicolumn{6}{|c|}{ Description of Respondents } & \multirow[t]{2}{*}{ WA } & \multirow[t]{2}{*}{ SD } & \multirow{2}{*}{$\begin{array}{c}\text { Z-test } \\
\text { Cal. } \\
\text { Value }\end{array}$} & \multirow{2}{*}{$\begin{array}{c}\text { Z-test } \\
\text { Cri. } \\
\text { Value }\end{array}$} \\
\hline & SD & $\mathrm{D}$ & $\mathrm{N}$ & A & SA & Total & & & & \\
\hline Number & 33 & 49 & 43 & 85 & 20 & 230 & 3.04 & 1.22 & 0.50 & 1.96 \\
\hline Percentage & 14.35 & 21.30 & 18.70 & 36.96 & 8.69 & 100 & - & - & - & - \\
\hline
\end{tabular}

Source: Field Survey, 2018

$H_{0}=$ Female entrepreneurs can't utilize their skills fully.

$\mathrm{H}_{1}=$ Female entrepreneurs can utilize their skills fully.

From the above table it is clear to us that about $14.35 \%$ respondents strongly disagreed, $21.30 \%$ respondents disagreed, $18.70 \%$ respondents are neutral, $36.96 \%$ respondents agreed and $08.69 \%$ respondents strongly agreed that female entrepreneurs can utilize their skills fully. Here, the calculated value of $Z$ is 0.50 and the critical value of $Z$ is 1.96 . As the critical value of $Z$ is greater than the calculated value of $Z$ so the null hypothesis $\left(\mathrm{H}_{0}\right)$ is accepted and alternative hypothesis $\left(\mathrm{H}_{1}\right)$ is rejected.

Comment: From the above mathematical analysis it has been seen that female entrepreneurs can't utilize their skills fully. Due to insufficient opportunity female entrepreneurs can't utilize their skills fully. It is a great obstacle for women's empowerment.

Factor\#08: Female entrepreneurs can express their opinion at any time without any complexity.

Table: 08

\begin{tabular}{|c|c|c|c|c|c|c|c|c|c|c|}
\hline & \multicolumn{6}{|c|}{ Description of Respondents } & \multirow[t]{2}{*}{ WA } & \multirow[t]{2}{*}{ SD } & \multirow{2}{*}{$\begin{array}{c}\text { Z-test } \\
\text { Cal. } \\
\text { Value }\end{array}$} & \multirow{2}{*}{$\begin{array}{c}\text { Z-test } \\
\text { Cri. } \\
\text { Value } \\
\end{array}$} \\
\hline & SD & $\mathrm{D}$ & $\mathrm{N}$ & A & SA & Total & & & & \\
\hline Number & 51 & 110 & 28 & 31 & 10 & 230 & 2.30 & 1.09 & -9.72 & 1.96 \\
\hline Percentage & 22.17 & 47.83 & 12.17 & 13.48 & 4.35 & 100 & - & - & - & - \\
\hline
\end{tabular}

Source: Field Survey, 2018

$H_{0}=$ Female entrepreneurs can't express their opinion at any time without any complexity. $\mathrm{H}_{1}=$ Female entrepreneurs can express their opinion at any time without any complexity.

From the total of our respondents it is found that, $22.17 \%$ respondents strongly disagreed, $47.83 \%$ respondents disagreed, $12.17 \%$ respondents are neutral, $13.48 \%$ respondents agreed and $04.35 \%$ respondents strongly agreed that female entrepreneurs can express their opinion at any time without any complexity. Here, the calculated value of $Z$ is -9.72 and the critical value of $Z$ is 1.96 As the critical value of $Z$ is greater than the calculated value of $Z$ so the null hypothesis $\left(\mathrm{H}_{0}\right)$ is accepted and alternative hypothesis $\left(\mathrm{H}_{1}\right)$ is rejected. 
Comment: Mathematical analysis reveals that, female entrepreneurs' opportunity to express their opinion at any time is not sufficient. They can't express their opinion without complexity. Such type of discrimination acts as obstacles for women's empowerment. So opportunity should be created to enhance expressing power of women about important matters.

Factor\#09: Traditional values and attitudes of general people regarding social mobility of women to go for decision making are good.

Table: 09

\begin{tabular}{|c|c|c|c|c|c|c|c|c|c|c|}
\hline & \multicolumn{6}{|c|}{ Description of Respondents } & \multirow[t]{2}{*}{ WA } & \multirow[t]{2}{*}{$\mathrm{SD}$} & \multirow{2}{*}{$\begin{array}{c}\text { Z-test } \\
\text { Cal. } \\
\text { Value }\end{array}$} & \multirow{2}{*}{$\begin{array}{l}\text { Z-test } \\
\text { Cri. } \\
\text { Value }\end{array}$} \\
\hline & SD & $\mathrm{D}$ & $\mathrm{N}$ & A & SA & Total & & & & \\
\hline Number & 39 & 94 & 56 & 34 & 07 & 230 & 2.46 & 1.03 & -7.94 & 1.96 \\
\hline Percentage & 16.96 & 40.87 & 24.35 & 14.78 & 3.04 & 100 & - & - & - & - \\
\hline
\end{tabular}

Source: Field Survey, 2018

$H_{0}=$ Traditional values and attitudes of general people regarding social mobility of women togo for decision making is not good.

$\mathrm{H}_{1}=$ Traditional values and attitudes of general people regarding social mobility of women to go for decision making is good.

From data collection process it has been found that, $16.96 \%$ respondents strongly disagreed, $40.87 \%$ respondents disagreed, $24.35 \%$ respondents are neutral, $14.78 \%$ respondents agreed and $03.04 \%$ respondents strongly agreed that traditional values and attitudes of general people regarding social mobility of women to go for decision making is good. Here, the calculated value of $Z$ is 4.65 and the critical value of $Z$ is 1.96 . As the critical value of $Z$ is smaller than the calculated value of $Z$ so the null hypothesis $\left(\mathrm{H}_{0}\right)$ is rejected and alternative hypothesis $\left(\mathrm{H}_{1}\right)$ is accepted.

Comment: In our society attitudes of general people regarding social mobility of women to go for decision making is not good. It is a serious obstacle for women empowerment. Women are discouraged to involve in economic activities from his family and society. So, proper steps should be taken to change attitude of general people towards women.

Factor\#10: Biasness exists between male and female entrepreneurs.

Table: 10

\begin{tabular}{|c|c|c|c|c|c|c|c|c|c|c|}
\hline & \multicolumn{6}{|c|}{ Description of Respondents } & \multirow[t]{2}{*}{ WA } & \multirow[t]{2}{*}{ SD } & \multirow{2}{*}{$\begin{array}{c}\text { Z-test } \\
\text { Cal. } \\
\text { Value }\end{array}$} & \multirow{2}{*}{$\begin{array}{c}\text { Z-test } \\
\text { Cri. } \\
\text { Value }\end{array}$} \\
\hline & SD & $\mathrm{D}$ & $\mathrm{N}$ & A & SA & Total & & & & \\
\hline Number & 20 & 39 & 33 & 98 & 40 & 230 & 3.43 & 1.20 & 5.44 & 1.96 \\
\hline Percentage & 8.70 & 16.96 & 14.35 & 42.61 & 17.38 & 100 & - & - & - & - \\
\hline
\end{tabular}

Source: Field Survey, 2018

$H_{0}=$ There exists no biasness between male and female entrepreneurs.

$\mathrm{H}_{1}=$ There exists biasness between male and female entrepreneurs.

$08.70 \%$ respondents strongly disagreed, $16.96 \%$ respondents disagreed, $14.35 \%$ respondents are neutral, $42.61 \%$ respondents agreed and $17.38 \%$ respondents strongly agreed that there exists biasness between male and female entrepreneurs. As the calculated value of $Z$ is 6.17 and the critical value of $Z$ is 1.96 , so the null hypothesis $\left(\mathrm{H}_{0}\right)$ is rejected and alternative hypothesis $\left(\mathrm{H}_{1}\right)$ is accepted. 
Comment: The above mathematical analysis shows that serious biasness and discrimination exists between male and female entrepreneurs. In most of the cases male entrepreneurs give priority over female entrepreneurs. In case of decision making also female entrepreneurs get less opportunity than male entrepreneurs. It is a serious matter of concern. So, concerned authority should take proper steps to remove this kind of biasness.

Factor\#11: Proper training and development facilities are available to make women as an efficient decision maker.

Table: 11

\begin{tabular}{|c|c|c|c|c|c|c|c|c|c|c|}
\hline & \multicolumn{6}{|c|}{ Description of Respondents } & \multirow[t]{2}{*}{ WA } & \multirow[t]{2}{*}{ SD } & \multirow{2}{*}{$\begin{array}{c}\text { Z-test } \\
\text { Cal. } \\
\text { Value }\end{array}$} & \multirow{2}{*}{$\begin{array}{c}\text { Z-test } \\
\text { Cri. } \\
\text { Value }\end{array}$} \\
\hline & SD & $\mathrm{D}$ & $\mathrm{N}$ & A & SA & Total & & & & \\
\hline Number & 32 & 84 & 34 & 64 & 16 & 230 & 2.77 & 1.19 & -2.95 & 1.96 \\
\hline Percentage & 13.91 & 36.52 & 14.78 & 27.83 & 6.96 & 100 & - & - & - & - \\
\hline
\end{tabular}

Source: Field Survey, 2018

$H_{0}=$ Proper training and development facilities are not available to make women as an efficient decision maker.

$\mathrm{H}_{1}=$ Proper training and development facilities are available to make women as an efficient decision maker.

From the total of our respondents it is found that, $13.91 \%$ respondents strongly disagreed, $36.52 \%$ respondents disagreed, $14.78 \%$ respondents are neutral, $27.83 \%$ respondents agreed and $06.96 \%$ respondents strongly agreed that proper training and development facilities are available to make women as an efficient decision maker. Here, the calculated value of $Z$ is -2.95 and the critical value of $Z$ is 1.96 . As the critical value of $Z$ is greater than the calculated value of $\mathrm{Z}$ so the null hypothesis $\left(\mathrm{H}_{0}\right)$ is accepted and alternative hypothesis $\left(\mathrm{H}_{1}\right)$ is rejected.

Comment: Most of the respondents argued that, proper training and development facilities are not available to make women as efficient decision maker. Maximum woman who are presently involved in business arena is not properly trained up. Due to insufficient training female entrepreneurs can't handle their operations effectively. To accelerate the women empowerment process proper training and development facilities for women should be enhanced.

Factor\#12: Women entrepreneurs get expected supports and assistance from government and business regulated agencies when necessary.

Table: 12

\begin{tabular}{|c|c|c|c|c|c|c|c|c|c|c|}
\hline & \multicolumn{6}{|c|}{ Description of Respondents } & \multirow[t]{2}{*}{ WA } & \multirow[t]{2}{*}{$\mathrm{SD}$} & \multirow{2}{*}{$\begin{array}{c}\text { Z-test } \\
\text { Cal. } \\
\text { Value }\end{array}$} & \multirow{2}{*}{$\begin{array}{c}\text { Z-test } \\
\text { Cri. } \\
\text { Value }\end{array}$} \\
\hline & SD & $\mathrm{D}$ & $\mathrm{N}$ & A & SA & Total & & & & \\
\hline Number & 54 & 112 & 29 & 31 & 04 & 230 & 2.21 & 1.00 & -11.97 & 1.96 \\
\hline Percentage & 23.48 & 48.70 & 12.61 & 13.48 & 1.73 & 100 & - & - & - & - \\
\hline
\end{tabular}

Source: Field Survey, 2018

$H_{0}=$ Female entrepreneurs can't get expected supports and assistance from government and business regulated agencies when necessary.

$\mathrm{H}_{1}=$ Female entrepreneurs get expected supports and assistance from government and business regulated agencies when necessary. 
From the above table it is clear to us that, about $23.48 \%$ respondents strongly disagreed, $48.70 \%$ respondents disagreed, $12.61 \%$ respondents are neutral, $13.48 \%$ respondents agreed and $01.73 \%$ respondents strongly agreed that female entrepreneurs get expected supports and assistance from government and business regulated agencies when necessary. Here, the calculated value of $Z$ is -3.38 and the critical value of $Z$ is 1.96 . As the critical value of $Z$ is greater than the calculated value of $Z$ so the null hypothesis $\left(\mathrm{H}_{0}\right)$ is accepted and alternative hypothesis $\left(\mathrm{H}_{1}\right)$ is rejected.

Comment: Female entrepreneurs strongly argued that they can't get expected supports and assistance from government and business regulated agencies when necessary. As a result they can't run their business operation smoothly. Without proper support it is really very difficult to carry on business operations. So it is a burning need for female entrepreneurs to get enough supports and assistance from government and business regulated agencies when necessary.

Factor\#13: Female entrepreneurs are fully aware about their rights.

Table: 13

\begin{tabular}{|c|c|c|c|c|c|c|c|c|c|c|}
\hline & \multicolumn{6}{|c|}{ Description of Respondents } & \multirow[t]{2}{*}{ WA } & \multirow[t]{2}{*}{ SD } & \multirow{2}{*}{$\begin{array}{c}\text { Z-test } \\
\text { Cal. } \\
\text { Value }\end{array}$} & \multirow{2}{*}{$\begin{array}{c}\text { Z-test } \\
\text { Cri. } \\
\text { Value } \\
\end{array}$} \\
\hline & SD & $\mathrm{D}$ & $\mathrm{N}$ & A & SA & Total & & & & \\
\hline Number & 11 & 84 & 38 & 76 & 21 & 230 & 3.05 & 1.11 & -0.68 & 1.96 \\
\hline Percentage & 4.78 & 36.52 & 16.52 & 33.04 & 9.14 & 100 & - & - & - & - \\
\hline
\end{tabular}

Source: Field Survey, 2018

$H_{0}=$ Female entrepreneurs are not fully aware about their rights.

$\mathrm{H}_{1}=$ Female entrepreneurs are fully aware about their rights.

From the above table it has been found that, $04.78 \%$ respondents strongly disagreed, $36.52 \%$ respondents disagreed, $16.52 \%$ respondents are neutral, $33.04 \%$ respondents agreed and $09.14 \%$ respondents strongly agreed that female entrepreneurs are fully aware about their rights. Since the calculated value of $Z$ is 0.68 and the critical value of $Z$ is 1.96 , so the null hypothesis $\left(H_{0}\right)$ is accepted and alternative hypothesis $\left(\mathrm{H}_{1}\right)$ is rejected.

Comment: One of the most crucial causes for slow women empowerment is that female entrepreneurs are not fully aware about their rights. They are not fully conscious about their legal rights. This kind of unconsciousness creates due to lack of proper education. So, concerned authority should initiate proper steps to raise awareness among woman.

Factor\#14: Women have full freedom in participating of local and national politics.

Table: 14

\begin{tabular}{|c|c|c|c|c|c|c|c|c|c|c|}
\hline & \multicolumn{6}{|c|}{ Description of Respondents } & \multirow[t]{2}{*}{ WA } & \multirow[t]{2}{*}{ SD } & \multirow{2}{*}{$\begin{array}{c}\text { Z-test } \\
\text { Cal. } \\
\text { Value }\end{array}$} & \multirow{2}{*}{$\begin{array}{c}\text { Z-test } \\
\text { Cri. } \\
\text { Value } \\
\end{array}$} \\
\hline & SD & $\mathrm{D}$ & $\mathrm{N}$ & A & SA & Total & & & & \\
\hline Number & 28 & 70 & 34 & 86 & 12 & 230 & 2.93 & 1.17 & -0.91 & 1.96 \\
\hline Percentage & 12.17 & 30.43 & 14.78 & 37.39 & 5.23 & 100 & - & - & - & - \\
\hline
\end{tabular}

Source: Field Survey, 2018

$H_{0}=$ Female have no full freedom in participating of local and national politics.

$\mathrm{H}_{1}=$ Female have full freedom in participating of local and national politics. 
From the survey it has been seen that, $12.17 \%$ respondents strongly disagreed, $30.43 \%$ respondents disagreed, $14.78 \%$ respondents are neutral, $37.39 \%$ respondents agreed and $05.23 \%$ respondents strongly agreed that women have full freedom in participating of local and national politics. Here, the calculated value of $Z$ is -0.91 and the critical value of $Z$ is 1.96 . As the critical value of $Z$ is greater than the calculated value of $Z$ so the null hypothesis $\left(H_{0}\right)$ is accepted and alternative hypothesis $\left(\mathrm{H}_{1}\right)$ is rejected.

Comment: Mathematical analysis have proved that, women can't get full freedom in participating of local and national politics. They are hindered by his family and society. As female entrepreneurs consist of half of total population, so their participation in local and national politics is very necessary.

Factor\#15: Roles regarding promotion of women entrepreneurs to make them as decision makers of mainstream chambers are sufficient.

Table: 15

\begin{tabular}{|c|c|c|c|c|c|c|c|c|c|c|}
\hline & \multicolumn{6}{|c|}{ Description of Respondents } & \multirow[t]{2}{*}{ WA } & \multirow[t]{2}{*}{ SD } & \multirow{2}{*}{$\begin{array}{c}\text { Z-test } \\
\text { Cal. } \\
\text { Value }\end{array}$} & \multirow{2}{*}{$\begin{array}{c}\text { Z-test } \\
\text { Cri. } \\
\text { Value } \\
\end{array}$} \\
\hline & SD & $\mathrm{D}$ & $\mathrm{N}$ & $\vec{A}$ & SA & Total & & & & \\
\hline Number & 28 & 108 & 35 & 56 & 03 & 230 & 2.56 & 1.02 & -6.56 & 1.96 \\
\hline Percentage & 12.17 & 46.96 & 15.22 & 24.35 & 1.30 & 100 & - & - & - & - \\
\hline
\end{tabular}

Source: Field Survey, 2018

$H_{0}=$ Roles regarding promotion of female entrepreneurs to make them as decisionmakers of mainstream chambers are not sufficient.

$H_{1}=$ Roles regarding promotion of female entrepreneurs to make them as decisionmakers of mainstreamchambers are sufficient.

From the total of our respondents it has been found that, about $12.17 \%$ respondents strongly disagreed, $46.96 \%$ respondents disagreed, $15.22 \%$ respondents are neutral, $24.35 \%$ respondents agreed and $01.30 \%$ respondents strongly agreed that organization practices office utility management. As the calculated value of $Z$ is -6.56 is smaller than the critical value of $Z$ is 1.96 , so the null hypothesis $\left(\mathrm{H}_{0}\right)$ is rejected and alternative hypothesis $\left(\mathrm{H}_{1}\right)$ is accepted.

Comment: From the above mathematical analysis it is very much clear to us that, roles regarding promotion of women entrepreneurs to make them as decision makers of mainstream chambers are not sufficient. So, mainstream chambers should concern to develop female entrepreneurs.

Factor\#16: Coordination between and among different institutions working for women entrepreneurs development is sufficient.

Table: 16

\begin{tabular}{|c|c|c|c|c|c|c|c|c|c|c|}
\hline & \multicolumn{6}{|c|}{ Description of Respondents } & \multirow[t]{2}{*}{ WA } & \multirow[t]{2}{*}{ SD } & \multirow{2}{*}{$\begin{array}{c}\text { Z-test } \\
\text { Cal. } \\
\text { Value }\end{array}$} & \multirow{2}{*}{$\begin{array}{c}\text { Z-test } \\
\text { Cri. } \\
\text { Value }\end{array}$} \\
\hline & SD & $\mathrm{D}$ & $\mathrm{N}$ & A & SA & Total & & & & \\
\hline Number & 25 & 77 & 55 & 69 & 04 & 230 & 2.78 & 1.04 & -3.19 & 1.96 \\
\hline Percentage & 10.87 & 33.43 & 23.91 & 30.00 & 1.74 & 100 & - & - & - & - \\
\hline
\end{tabular}

Source: Field Survey, 2018

$H_{0}=$ There is no coordination between and among different institutions working for female entrepreneurs development. 


\section{$\mathrm{H}_{1}=$ There is coordination between and among different institutions working for female entrepreneurs development.}

From the total of our respondents it is found that, $10.87 \%$ respondents strongly disagreed, $33.48 \%$ respondents disagreed, $23.91 \%$ respondents are neutral, $30.00 \%$ respondents agreed and $01.74 \%$ respondents strongly agreed that there is availability of transport facilities. Here, the calculated value of $Z$ is -2.31 and the critical value of $Z$ is 1.96 . As the critical value of $Z$ is greater than the calculated value of $Z$ so the null hypothesis $\left(\mathrm{H}_{0}\right)$ is accepted and alternative hypothesis $\left(\mathrm{H}_{1}\right)$ is rejected.

Comment: Coordination among different institutions working for female entrepreneurs' development is very poor. So, proper steps should be taken to increase coordination among different institutions working for female entrepreneurs' development.

\section{Recommendations}

Women empowerment is one of the most important issues in the present day of the world. Though women have a great involvement in the development process, they have low status as compared to men, specifically in the developing world. The situation is almost same in Bangladesh. Bangladesh development process will not get pace without the further involvement of the women. However some recommendations and suggestions are designed bellow for improving decision making capacity of women entrepreneurs in business arena:

- Bangladesh Women Chamber of Commerce and Industry (BWCCI) and other women organizations together with male counterpart have to continue their voices to influence the government to undertake policy measures and implement them properly for developing female entrepreneurs' decision making capability.

- People from all walks of life should work together to remove existing social barriers and create an enabling environment for women entrepreneurs in Bangladesh.

- National Women Development Policy 2008 should be properly implemented.

- Government and business regulated agencies should ensure equal opportunity to male and female entrepreneurs in case of policy formulation and decision making

- Decisions taken by women entrepreneurs should be honored, accepted and properly implemented by the concerned authority and attitudes of general people towards women entrepreneurs should be changed.

- Govt. should ensure that women entrepreneurs can utilize their skills fully.

- Concerned authority should take proper steps to eradicate discrimination between male and female entrepreneurs and raise awareness among women entrepreneurs.

- Maintain a quota for women entrepreneurs in the project undertaken by respective ministries and make sure that this quota is maintained properly. Besides this coordination can be increased between and among different ministries and institutions that are involved in women entrepreneurship development activities.

- Establish women entrepreneurship development academy for the capacity development of the women entrepreneurs and introduce a holistic program for capacity building of women entrepreneurs.

- Extend social network for women entrepreneurs to make them as efficient decision maker.

- Education system should have some mechanism to change social attitudes towards women entrepreneurs and harmony and coordination between and among policy institutions to improve women entrepreneur can be ensured.

- Improve law and order situation in order to ensure fear free environment for business community, especially for women entrepreneurs. 


\section{Conclusion}

One of the reports of (UNIFEM, 2004) indicates 7 Principles to make women empower in the corporate world: Equality should be created among man and women. Top business leadership must promote the gender equality through their policies and should promote healthy and safety measure to feel the women secure at workplace. Government should also establish the programs and training plans that increase the education and awareness level among women. Moreover concerned authority should promote the women owned businesses by expanding the relationships with their companies and should recognize the women leadership in communities and in public. In addition companies must be held accountable for their women empowerment and gender equality policies.

We conclude our discussion on the points that the present condition of women empowerment and participation in policy formulation and decision making process is not so good in Bangladesh's corporate sector. Although now a days women are engaged in various but women's' participation in policy formulation and decision making process is very poor due to the number of reasons indicated in the research. But these issues can be overcome through the measures suggested in this research paper especially the principles suggested by the (UNIFEM, 2004). The dream of empowering the women in the corporate sector can be come true by increasing their participation in the economic activities. And it can be hoped that in future women empowerment condition will be better than the past.

\section{References:}

Khan, Dr. A.R. (2006). Entrepreneurship Small Business and Lives of Successful Entrepreneurs. Dhaka.

Hossain, M., \&Jaim, W. M. H. (2011, January).Empowering Women to Become Farmer Entrepreneur. In Paper presented at the IFAD Conference on New Directions for Smallholder Agriculture (Vol. 24, p. 25).

GU, B., 2005. Empowerment of Rural Women through Income Generating Activities in Gadag District on Northern Karnataka. University of Agricultural Sciences.

Parvin, L., Jinrong, J., \&Rahman, M. W. (2012). Women entrepreneurship development in Bangladesh: What are the challenges ahead? African Journal of Business Management, 6(11), 3862.

Majumdar, Rozana (2012), Are Bangladeshi Women Politicians Tokens in the Political Arena?, http://asiafoundation.org/in-asia/2012/06/27; Viewed on 05.12.2012

Parveen, S. \&Leonhäuser, I. U. 2005. Empowerment of rural women in Bangladesh: a household level analysis, Margraf. [Online]. Available from: http://www.tropentag.de/2004/abstracts/full/382.pdf. [Accessed 10/03/12].

Laizu, Z., Armarego, J., \&Sudweeks, F. (2010, December).Cognitive change in women's empowerment in rural Bangladesh. In Computer and Information Technology (ICCIT), 2010 13th International Conference on (pp. 277-282). IEEE.

ILO Area Office (2009), Women's Participation in Trade Unions in Bangladesh: Status, Barriers and Overcoming Strategies, 
Journal of Business School, vol.2, issue.3, pp.40-55

World Conference on Women, \& United Nations. (1996). Report of the Fourth World Conference on Women: Beijing, 4-15 September 1995.

Khan, M. R., \&Ara, F. (2006). Women, participation and empowerment in local government: Bangladesh union Parishad perspective. Asian Affairs, 29(1), 73-92. 